\title{
Glucose Repression of Carbon Source Uptake and Metabolism in Streptomyces coelicolor A3(2) and its Perturbation in Mutants Resistant to 2-Deoxyglucose
}

\author{
By DAVID A. HODGSON† \\ John Innes Institute, Colney Lane, Norwich NR4 7UH, U.K.
}

(Received 25 November 1981; revised 28 April 1982)

\begin{abstract}
A newly devised method to obtain diffuse growth of Streptomyces coelicolor A3(2) in liquid minimal medium was used to study glucose repression. Although diauxic growth was not obtained, glucose repression of uptake of ${ }^{14} \mathrm{C}$-labelled carbon sources was demonstrated. Active, arabinose-induced, arabinose transport was repressed at the level of transcription by glucose. Of two glycerol-inducible glycerol transport systems, one was glucose-inhibited but not repressed (and operated by facilitated diffusion), whilst the other (an active transport system) was glucose-repressed. Active transport systems for galactose and fructose which did not require induction by their respective sugars were both inhibited by glucose. Galactose- and fructosemetabolizing enzymes were inducible by the respective sugars, but only in the absence of glucose. This was because glucose both inhibited galactose and fructose transport and repressed the metabolic enzymes concerned. Constitutive active glucose uptake was also demonstrated in arabinose-grown cells. Mutants that grew on arabinose or glycerol in the presence of 2-deoxyglucose were glucose-derepressed for both soluble carbon source utilization and extracellular agarose.'Three glucose-derepressed mutants were studied in detail. One of these could not utilize glucose (and probably lacks glucose kinase), whilst the other two could utilize glucose to differing degrees.
\end{abstract}

\section{INTRODUCTION}

Streptomycetes are among the most numerous and ubiquitous of soil micro-organisms. Some of the major reasons for their study are their morphological complexity (unusual among prokaryotes), their extraordinary ability to produce antibiotics (leading to commercial exploitation of the group on a large scale), and their ability to produce numerous extracellular enzymes. Most work on metabolic regulation has been concerned with control of antibiotic synthesis and in many cases there is evidence of glucose repression (Martin \& Demain, 1980). Unfortunately, relatively little attention has been paid to the regulation of primary carbon source metabolism in these organisms. This paper describes a system of glucose repression of carbon source uptake and metabolism and the isolation of mutants in this system in Streptomyces coelicolor A3(2) ( $S$. violaceoruber: Kutzner \& Waksman, 1959), genetically the best characterized streptomycete (Hopwood et al., 1973).

\section{METHODS}

Media. Complete medium (CM) and minimal medium (MM) and its supplements were prepared as described by Hopwood (1967). Sporulation medium (from American Type culture Collection catalogue, medium 5) contained $\left(\mathrm{g} \mathrm{l}^{-1}\right)$ : yeast extract, 1 ; beef extract, 1 ; tryptose, $2 ; \mathrm{FeSO}_{4} .7 \mathrm{H}_{2} \mathrm{O}, 0.01$; glucose, 10 ; and agar, 15. The $\mathrm{pH}$

$\dagger$ Present address: Department of Molecular Biology, Albert Einstein College of Medicine, Bronx, New York, N.Y. 10461, U.S.A.

Abbreviations: BM, buffered minimal medium; BMA, buffered minimal medium without antifoaming agent; CM, complete medium; DOG, 2-deoxyglucose; HCM, Hirsch complex medium; MM, minimal medium; NMM, modified minimal medium; NMMB, buffered solid medium; NTG, $N$-methyl- $N^{\prime}$-nitro- $N$-nitrosoguanidine; PEG, polyethylene glycol. 
Table 1. S. coelicolor A3(2) strains used

\begin{tabular}{|c|c|c|c|c|}
\hline $\begin{array}{c}\text { Strain } \\
\text { no. }\end{array}$ & Genotype & $\begin{array}{l}\text { SCP1 } \\
\text { status }\end{array}$ & $\begin{array}{c}\mathrm{SCP} 2 \\
\text { status } \dagger\end{array}$ & Source \\
\hline 1098 & pheAl & - & + & JII collection \\
\hline 1190 & hisAl uraAl strAl & - & + & JII collection \\
\hline M130 & hisAl uraAl strAl & - & - & JII collection \\
\hline $\mathrm{J} 650 \ddagger$ & mthB2 cysD 18 agaA7 & NF & *? & JII collection \\
\hline $\mathrm{J} 802 \ddagger$ & $\operatorname{agaA7}$ & NF & *? & $\mathrm{J} 650 \times 1098$ \\
\hline J845 & $\operatorname{agaA7} \operatorname{dog}-1$ & NF & *? & J802 spontaneous mutant \\
\hline $\mathrm{J} 846 t$ & $\operatorname{agaA} 7 \operatorname{dog}-2$ & NF & $* ?$ & J802 spontaneous mutant \\
\hline $\mathrm{J} 847 \ddagger$ & agaA 7 dog-3 & NF & *? & J802 spontaneous mutant \\
\hline $\mathrm{J} 855^{\top}$ & hisAl uraAl strAl dog-5 & - & - & M130 NTG mutant \\
\hline
\end{tabular}

† Several NF strains (with the plasmid SPCl integrated into the chromosome in the 'Normal Fertility' mode) (not including those within this Table) have been tested and found to contain the SCP2* form of SCP2, i.e. enhanced sex factor activity (M. J. Bibb, personal communication).

$\ddagger$ The presence of integrated SCP1 (NF) and the agaA7 lesion results in a strain unable to use agar as a carbon source (Hodgson \& Chater, 1981).

was adjusted to 7.2 before autoclaving. Minimal medium was sometimes modified by replacement of asparagine $\left(0.5 \mathrm{~g} \mathrm{l}^{-1}\right)$ by $\mathrm{NH}_{4} \mathrm{SO}_{4}\left(1 \mathrm{~g} \mathrm{l}^{-1}\right)$ to give NMM. A buffered solid medium (NMMB) for testing the use of different carbon sources contained $\left(\mathrm{g} \mathrm{l}^{-1}\right):\left(\mathrm{NH}_{4}\right)_{2} \mathrm{SO}_{4}, 1 ; \mathrm{K}_{2} \mathrm{HPO}_{4}, 0 \cdot 5 ; \mathrm{MgSO}_{4} \cdot 7 \mathrm{H}_{2} \mathrm{O}, 0 \cdot 2 ; \mathrm{FeSO}_{4} .7 \mathrm{H}_{2} \mathrm{O}, 0 \cdot 01 ;$ agar, 15 ; and $0.015 \mathrm{M}$-phosphate buffer $\left(\mathrm{NaH}_{2} \mathrm{PO}_{4} / \mathrm{K}_{2} \mathrm{HPO}_{4}\right)$, pH 6.8. Buffered minimal medium (BM) contained ( $\left.\mathrm{g} \mathrm{l}^{-1}\right)$ : polyethylene glycol (PEG 6000), $5 ; \mathrm{NH}_{4} \mathrm{NO}_{3}, 2 ; \mathrm{MgSO}_{4} .7 \mathrm{H}_{2} \mathrm{O}, 0 \cdot 6 ; \mathrm{FeSO}_{4} .7 \mathrm{H}_{2} \mathrm{O}, 0.001 ; \mathrm{MnCl}_{2} .4 \mathrm{H}_{2} \mathrm{O}, 0 \cdot 001$; $\mathrm{ZnSO}_{4} .7 \mathrm{H}_{2} \mathrm{O}, 0.001 ; \mathrm{CaCl}_{2}, 0.001$; antifoaming agent, 0.15 ; and $0.015 \mathrm{M}$-phosphate buffer, pH 6.8. Carbon sources were added as follows: arabinose, cellobiose, galactose, glucose and glycerol, each at $10 \mathrm{~mm}$; and fructose at $50 \mathrm{~mm}$ in liquid medium and $20 \mathrm{~mm}$ in solid medium. Triton $\mathrm{X}$ buffer contained $0.06 \mathrm{M}$-Tris/ $\mathrm{HCl}$ buffer, $\mathrm{pH} 8 \cdot 3$, with $0.01 \mathrm{~g}$ Triton $\mathrm{X}-100 \mathrm{l}^{-1}$. Hirsch complex medium (HCM) contained $\left(\mathrm{g} \mathrm{l}^{-1}\right): \mathrm{MgSO}_{4} .7 \mathrm{H}_{2} \mathrm{O}, 0.01 ; \mathrm{CaCl}_{2}$, 0.02; Triton X-100, 0.01; yeast extract, 10 ; vitamin- and salt-free Casamino acids, 10 ; and $0.1 \mathrm{M}-\mathrm{Tris} / \mathrm{HCl}$ buffer, pH $7 \cdot 3$ (C. Hirsch, personal communication).

Chemicals. Rhodosil antimousse 426R (antifoaming agent) was a gift of Dr A. Sabatier, Rhone-Poulenc, Vitrysur-Seine, France, and rifampicin was a gift (to Dr K. F. Chater) from Dr J. Neusch, Ciba-Geigy, Basle, Switzerland; chloramphenicol, $\alpha$-methylglucoside and 2-deoxyglucose were obtained from Sigma; unlabelled carbon sources and PEG 6000 from BDH; and ${ }^{14} \mathrm{C}$-labelled carbon sources from Amersham.

Organisms and culture techniques. The strains (Table 1) were derived from Streptomyces coelicolor A3(2). Spores were prepared on CM as described by Hopwood (1967) unless they were to be used for uptake experiments when sporulation medium was used, since sporulation (especially with the 2-deoxyglucose-resistant strains) was heavier on this medium. Mutagenesis with $N$-methyl- $N^{\prime}$-nitro- $N$-nitrosoguanidine (NTG). was by the method of Hopwood et al. (1973).

Growth in liquid minimal medium. The normal mode of growth of $S$. coelicolor A3(2) in liquid MM is as mycelial pellets which are not suitable for physiological studies. The following procedure was developed from the observations that the addition to liquid MM of $50 \mathrm{~g} \mathrm{PEG} 6000 \mathrm{1}^{-1}$ and the use of stainless steel springs in the flask allowed diffuse growth of certain selected strains (Wheelis \& Wells, 1974; M. L. Wheelis, personal communication), and that heat-shocking and subsequent brief incubation of spores in a complex medium ensured rapid germination of $<90 \%$ of the spores (C. Hirsch, personal communication). Spores were pelleted by centrifugation in a $25 \mathrm{ml}$ bottle, resuspended in $0.3 \mathrm{ml}$ Triton $\mathrm{X}$ buffer, and incubated for $10 \mathrm{~min}$ at $50^{\circ} \mathrm{C}$ in a water bath (for heat-shock) before rapidly cooling in running tap water. $\mathrm{HCM}(10 \mathrm{ml})$ was then added and the bottle shaken for $2 \mathrm{~h}$ at $30^{\circ} \mathrm{C}$ in a rotary shaker before the spores were pelleted again. The newly germinated spores were finally resuspended in distilled water and dispensed (to give an initial $A_{450}$ of $0.02-0.05$ ) into flasks each containing a $20 \mathrm{~cm} \times 1.3 \mathrm{~cm}$ diameter stainless steel spring (Alliance Spring Co., London) with buffered medium (BM), and incubated at $30^{\circ} \mathrm{C}$ in an orbital shaker at about 200 r.p.m. When small volumes were required, $50 \mathrm{ml}$ in $250 \mathrm{ml}$ flasks was sufficient, otherwise $200 \mathrm{ml}$ medium in $500 \mathrm{ml}$ flasks was used.

Carbon source uptake studies. The following method was for the preparation of four uptake mixtures, from each of which nine samples could be taken. Cell cultures $(1.61,8 \times 200 \mathrm{ml}$ of BM) were harvested under vacuum at midexponential phase $A_{450}$ about 0.7 on a $15 \mathrm{~cm}$ filter paper (Whatman no. 1). After washing twice with $25 \mathrm{ml}$ prewarmed $\left(30^{\circ} \mathrm{C}\right) \mathrm{BM}$ without antifoaming agent (BMA) the cells were scraped off the filter with a spatula and transferred to a $100 \mathrm{ml}$ blender flask (MSE) containing $25 \mathrm{ml}$ prewarmed BMA. The cells were resuspended by blending at about 4700 r.p.m. for about $25 \mathrm{~s}$ in a $30^{\circ} \mathrm{C}$ water bath. Prewarmed BMA was added to a final volume of $44 \mathrm{ml}$ in such a manner as to rinse the blender blades. Of this suspension, $4 \mathrm{ml}$ was collected on a preweighed 
Millipore filter ( $0.65 \mu \mathrm{m}$ pore, $3.7 \mathrm{~cm}$ diameter) and washed with distilled water. After drying overnight in an oven

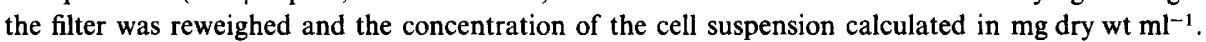

Cells were then preincubated with inhibitors, if involved, for $5 \mathrm{~min}$. At time zero, $10 \mathrm{ml}$ of the cell suspension was mixed with an equal volume of prewarmed BMA containing $20 \mathrm{mM}$ ( $40 \mathrm{~mm}$ in the case of fructose) of the ${ }^{14} \mathrm{C}$ labelled carbon source under test (about $2.5 \mu \mathrm{Ci} \mathrm{mmol}^{-1}, 92.5 \mathrm{kBq} \mathrm{mmol}^{-1}$ ) in a $50 \mathrm{ml}$ beaker covered with a water-filled watch glass to reduce losses due to evaporation. The reaction mixture was incubated at $30^{\circ} \mathrm{C}$ and agitated with a magnetic stirrer. At set times $2 \mathrm{ml}$ samples were taken (using a Pipetman P5000 automatic pipette) and collected on pre-wetted glass fibre filters (Whatman GF/C). Unbound ${ }^{14} \mathrm{C}$ label was removed by washing with $5 \mathrm{ml}$ ice-cold $10 \mathrm{mM}-\mathrm{KCN}$ in $0 \cdot 1 \mathrm{M}-\mathrm{NaCl}$. The filters were transferred to scintillation vials, $1 \mathrm{ml}$ of formamide was added and the vial was capped. After incubation for $2 \mathrm{~h}$ at $60^{\circ} \mathrm{C}$ to ensure solubilization of the cellular material (based on the procedure of Neujahr \& Ewaldsson, 1964) $10 \mathrm{ml}$ toluene scintillation fluid (toluene containing $5 \mathrm{~g}$ butyl-PBD $~^{-1}$ ) and $5 \mathrm{ml}$ absolute ethanol were added and the radioactivity was determined. Quench corrections were made using a standard curve. Uptake rates were consistent within cell batches but some variation was seen between batches (see Discussion).

Incorporation into TCA-precipitable counts. An uptake mixture was prepared as above. At set times a $2 \mathrm{ml}$ sample of the uptake mixture was transferred to $2 \mathrm{ml} \mathrm{TCA}(20 \%, \mathrm{w} / \mathrm{v})$. The precipitate was then transferred to a glass fibre filter (Whatman GF/B) and washed with $10 \mathrm{ml} \mathrm{TCA}(10 \%$, w/v) and $2 \mathrm{ml} 2 \mathrm{M}-\mathrm{HCl}$. After drying, the filter was counted in the toluene scintillation fluid described above.

Plate tests. Extracellular agarase production was assessed by Gran's test (Hodgson \& Chater, 1981). Possession of the plasmid SCP1 was detected by replicating patches of growth on to a CM plate spread with spores of an $\mathrm{SCP1}^{-}$strain (e.g. 1190), and assessing inhibition of the development of aerial mycelium of the latter (Vivian, 1971).

\section{RESULTS}

\section{Attempts to demonstrate glucose repression by growth in liquid medium}

Using the procedure outlined above for obtaining diffuse growth in liquid medium, an exponential increase in $A_{450}$ was obtained. The growth rates obtained using different carbon sources are given in Table 2. Many attempts were made, using many different conditions, to demonstrate a diauxic lag when $S$. coelicolor A3(2) strain $\mathrm{J} 802$ was grown in liquid BM in the presence of growth-limiting glucose $\left(0.56 \mathrm{~mm}\right.$ ) (growth ceased at an $A_{450}$ of 0.5$)$ and excess alternative carbon source (Hodgson, 1980). In the case of arabinose (10 mM) an initial uptake rate compatible with growth on glucose was followed by one compatible with that of growth on arabinose, implying diauxic growth. However, the change-over from growth on glucose to growth on arabinose was not marked by a detectable diauxic lag period. The addition of excess glucose to cells growing on arabinose led to a rapid increase in growth rate, comparable to that normally seen for glucose alone.

Table 2. Growth rates of $S$. coelicolor strain $J 802$ on various carbon sources

Cells were grown at $30^{\circ} \mathrm{C}$ in $200 \mathrm{ml} \mathrm{BM}$ in $500 \mathrm{ml}$ flasks containing a stainless steel spring. Values are the means of at least two determinations.

Carbon source* Doubling time (h)

$\begin{array}{lr}\text { Glucose } & 1.9 \\ \text { Arabinose } & 3 \cdot 9 \\ \text { Cellobiose } & 3 \cdot 6 \\ \text { Fructose }(50 \mathrm{~mm}) & 27 \cdot 7 \\ \text { Galactose } & 3 \cdot 6 \\ \text { Gluconate } & 2 \cdot 3 \\ \text { Glycerol } & 6 \cdot 3 \\ \text { Maltose } & 5 \cdot 1 \\ \text { Mannitol } & 6 \cdot 1 \\ \text { Mannose } & 4 \cdot 5 \\ \text { Pyruvate }(100 \mathrm{~mm}) & 5 \cdot 0 \text { then } 14.8 \\ \text { Rhamnose } & 2 \cdot 7\end{array}$

* Concentration $10 \mathrm{~mm}$ unless stated otherwise. 

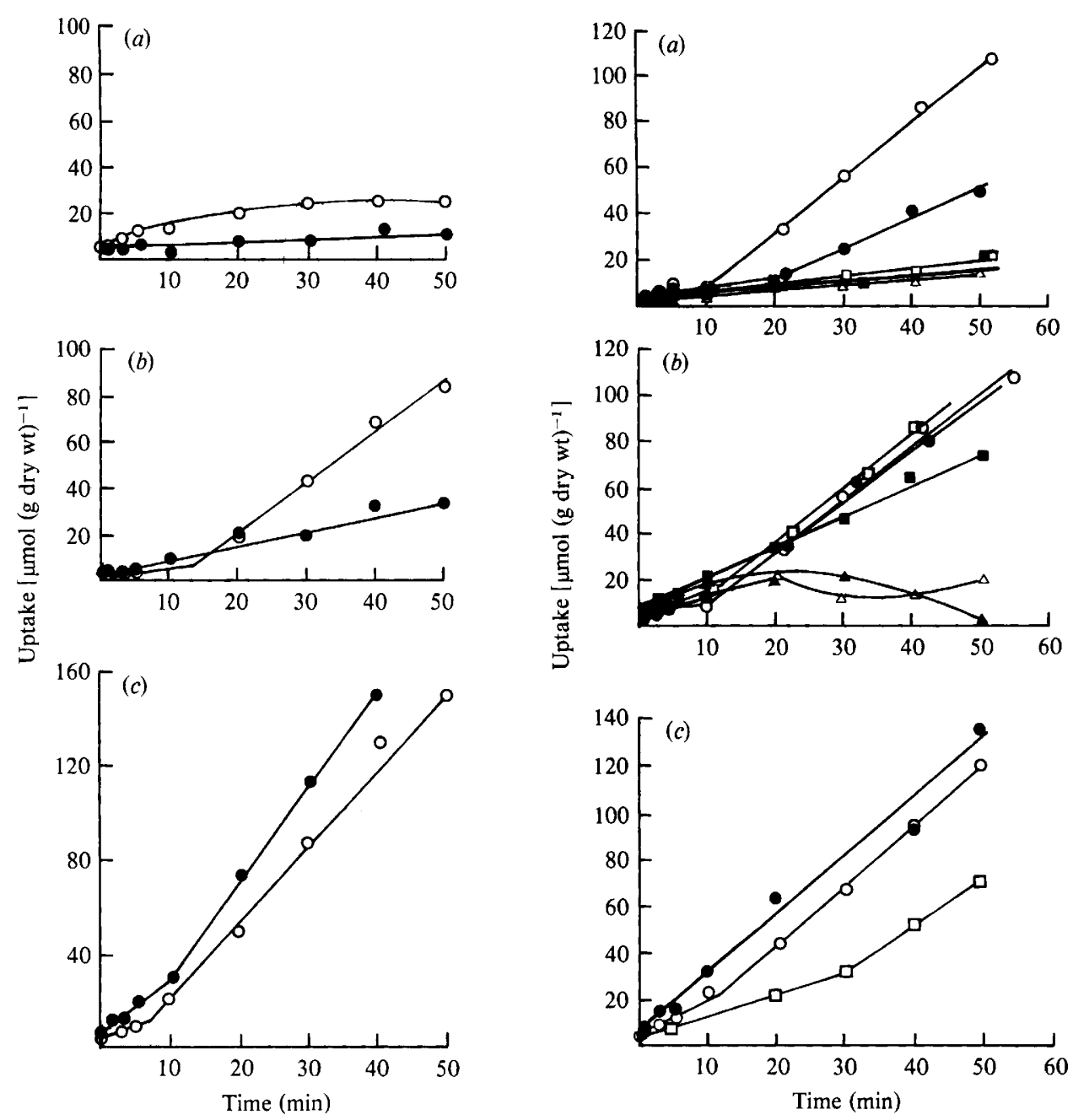

Fig. 1

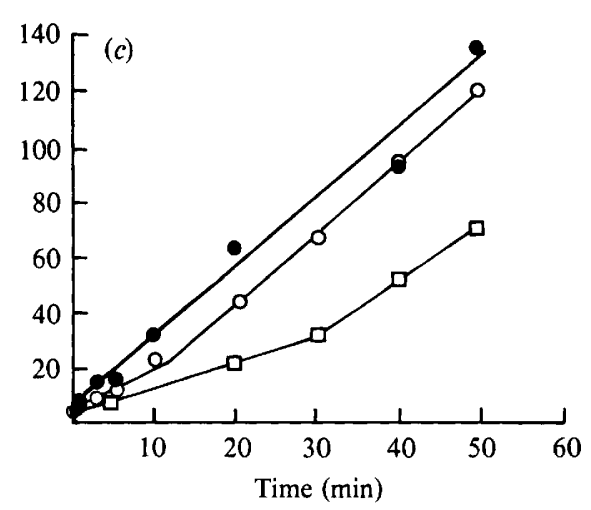

Fig. 2

Fig. 1. Uptake of $\mathrm{L}-\left[1-{ }^{14} \mathrm{C}\right]$ arabinose $(10 \mathrm{~mm})$ in the absence $(O)$ and presence $(O)$ of glucose $(10 \mathrm{~mm})$ in $(a)$ glucose-grown, $(b)$ glucose plus arabinose-grown and $(c)$ arabinose-grown $\mathbf{J} 802$ cells. Similar results were obtained in duplicate experiments.

Fig. 2. Effects of rifampicin and chloramphenicol on uptake of arabinose in the absence of glucose in arabinose-grown and glucose plus arabinose-grown $\mathrm{J} 802$ cells. Cells were preincubated with or without the antibiotics for $5 \mathrm{~min}$ before transfer to the uptake mixture. For each incubation, the rate of arabinose uptake is shown in square brackets. (a) Glucose plus arabinose-grown cells in the presence of rifampicin at $0 \mu \mathrm{g} \mathrm{ml}^{-1}(\mathrm{O})\left[2 \cdot 5 \mu \mathrm{mol} \mathrm{min}^{-1}\left(\mathrm{~g} \mathrm{dry} \mathrm{wt}^{-1}\right.\right.$ ], $20 \mu \mathrm{g} \mathrm{ml}^{-1}(\bigcirc)$ [1.3], $50 \mu \mathrm{g} \mathrm{ml}^{-1}(\square)[0 \cdot 7]$, $100 \mu \mathrm{g} \mathrm{ml}^{-1}(\square)[0]$ and $200 \mu \mathrm{g} \mathrm{ml}^{-1}(\triangle)[0]$. (b) Glucose plus arabinose-grown cells in the presence of chloramphenicol at $0 \mu \mathrm{g} \mathrm{ml}^{-1}(\mathrm{O})\left[2.5 \mu \mathrm{mol} \mathrm{min}^{-1}\left(\mathrm{~g} \mathrm{dry} \mathrm{wt}^{-1}\right], 5 \mu \mathrm{g} \mathrm{ml}^{-1}(\bigcirc)[2 \cdot 3], 10 \mu \mathrm{g} \mathrm{ml}^{-1}(\square)\right.$ $[2 \cdot 4], 20 \mu \mathrm{g} \mathrm{ml}^{-1}(\mathbf{\square})[1 \cdot 4], 50 \mu \mathrm{g} \mathrm{ml}^{-1}(\triangle)[0]$ and $100 \mu \mathrm{g} \mathrm{ml}^{-1}(\Delta)[0]$. (c) Arabinose-grown cells in the presence of no antibiotic (O) $\left[2.7 \mu \mathrm{mol} \mathrm{min}^{-1}(\mathrm{mg} \text { protein })^{-1}\right]$, chloramphenicol at $\left.100 \mu \mathrm{g} \mathrm{ml}^{-1}()^{\circ}\right)$ $[2 \cdot 7]$ and rifampicin at $200 \mu \mathrm{g} \mathrm{ml}^{-1}(\square)[1 \cdot 4]$.

\section{Glucose repression and arabinose uptake}

Uptake of $10 \mathrm{~mm}$-arabinose in the presence and absence of $10 \mathrm{~mm}$-glucose was investigated in cells grown on glucose alone, glucose plus arabinose, and arabinose alone (Fig. 1).

No significant uptake of arabinose, in either the presence or absence of glucose, was seen in glucose-grown cells (the low level of uptake that was seen may have been due to passive diffusion), demonstrating the lack of a constitutive uptake system. After pre-growth in arabin- 
ose alone, cells took up $\left[{ }^{14} \mathrm{C}\right]$ arabinose without an extended lag even in the presence of glucose in the uptake medium. The short lag [7.6 (range $\pm 4.6 \mathrm{~min}$ in 14 determinations)] seen in Fig. $1 c$ was presumably due to physiological shock during harvesting and/or to a large intracellular pool of unlabelled arabinose. Pre-growth in glucose plus arabinose caused a longer lag in the ability of the cells to take up arabinose (14.8 $\pm 4.3 \mathrm{~min}$ in nine determinations). Moreover, no arabinose uptake was seen if glucose was present. These results are compatible with glucose repression of induction of an arabinose uptake system, the critical comparison being between the failure of glucose to prevent arabinose uptake in cells pre-grown in arabinose alone, and its prevention of arabinose uptake in cells grown in glucose plus arabinose. The difference in the above lag times for arabinose uptake (in the absence of glucose) between the arabinose-grown and the glucose plus arabinose-grown cells indicated that about $7-15 \mathrm{~min}$ was required for derepression and expression.

The uptake of $\mathrm{L}-\left[1-{ }^{14} \mathrm{C}\right]$ arabinose into arabinose-grown cells was compared in cells that had been given a final wash with either $\mathrm{KCN}$ (to inhibit metabolism during processing) or TCA (to measure incorporation into macromolecules) after removal from the uptake mixture. The results indicated that after a $10 \mathrm{~min}$ lag period nearly all the uptake $\left[1.2 \mu \mathrm{mol}\right.$ arabinose $\mathrm{min}^{-1}$ $\left.(\mathrm{g} \mathrm{dry} \mathrm{wt})^{-1}\right]$ in the first $60 \mathrm{~min}$ remained in a soluble form, and that only after this period was there significant incorporation $\left[0 \cdot 2 \mu \mathrm{mol}\right.$ arabinose $\left.\min ^{-1}(\mathrm{~g} \text { dry wt })^{-1}\right]$ into macromolecules such as protein and nucleic acid.

Rifampicin and chloramphenicol maximally inhibited induction of arabinose uptake at $100 \mu \mathrm{g} \mathrm{ml}^{-1}$ and $50 \mu \mathrm{g} \mathrm{ml}^{-1}$, respectively (Fig. $2 a, b$ ). The antibiotics, even at double the concentration, did not inhibit arabinose uptake significantly in fully induced (arabinose-grown) cells (Fig. 2c). The concentration of rifampicin required to inhibit induction was the same as that found by Chater (1974, and unpublished results) to give $80 \%$ inhibition of RNA synthesis of $S$. coelicolor using whole cells, cell-free extracts, or purified RNA polymerase. Dinitrophenol at $1 \mathrm{mM}$ (an uncoupler of respiration from ATP synthesis), reduced arabinose uptake by arabinosegrown cells from $1.6 \mu \mathrm{mol}$ arabinose $\mathrm{min}^{-1}$ (g dry wt) ${ }^{-1}$ to 0 in duplicate control experiments. Similar results were obtained when a combination of $1 \mathrm{~mm}$-sodium iodoacetate and $30 \mathrm{~mm}$ sodium azide (inhibitors of glycolysis and respiration, respectively) were added.

\section{Glucose repression and glycerol uptake}

Glycerol uptake in the presence and absence of glucose in cells grown in glucose alone, glucose plus glycerol, and glycerol alone, is shown in Fig. 3. Glycerol uptake in glucose-grown cells was very low (this residual activity was possibly due to non-specific passive diffusion). Its reduction to zero when glucose was added to the uptake mixture may have been due to increased internal glycerol concentration resulting from glucose metabolism (product inhibition). With glycerol plus glucose-grown cells a relatively high initial uptake rate (compared with that in equivalent arabinose experiments; Fig. 1) was seen, which doubled after about $25 \mathrm{~min}$. This initial rate must have been due to a glycerol-induced, but glucose-non-repressible, uptake system (compare the uptake of glycerol in the absence of glucose, in glucose plus glycerol-grown and glucosegrown cells). However, the presence of glucose during the uptake experiment depressed the uptake rate, possibly by either direct inhibition or product inhibition.

The secondary uptake in glucose plus glycerol-grown cells may have been due to induction of a second, more efficient, system which was glucose repressible. Glycerol uptake in glycerol-grown cells, where this system should have been fully induced, was not subject to glucose inhibition, which could reflect the insensitivity of this transport system to glucose inhibition or, perhaps less likely (see Discussion), the lack of induction of an inducible glucose transport system in glycerolgrown cells.

Neither rifampicin $\left(100 \mu \mathrm{g} \mathrm{ml}^{-1}\right)$, nor chloramphenicol $\left(50 \mu \mathrm{g} \mathrm{ml}^{-1}\right)$ inhibited the initial uptake rate (see below) but both inhibited the secondary uptake step in glucose plus glycerolgrown cells [ 3.3 and 2.9 , and 2.5 and $2.7 \mu \mathrm{mol}_{\text {glycerol } \mathrm{min}^{-1} \text { ( } \mathrm{g} \text { dry wt) }}{ }^{-1}$ in respective duplicate controls]. Again, there was no effect on glycerol uptake $\left[1.6 \mu \mathrm{mol}\right.$ glycerol $\left.\mathrm{min}^{-1}(\mathrm{~g} \text { dry wt })^{-1}\right]$ in a fully induced, i.e. glycerol-grown system, indicating that the drugs were not acting in a nonspecific fashion. Glycerol uptake in glycerol-grown cells [5.5 and $6.6 \mu \mathrm{mol}$ glycerol min ${ }^{-1}$ 

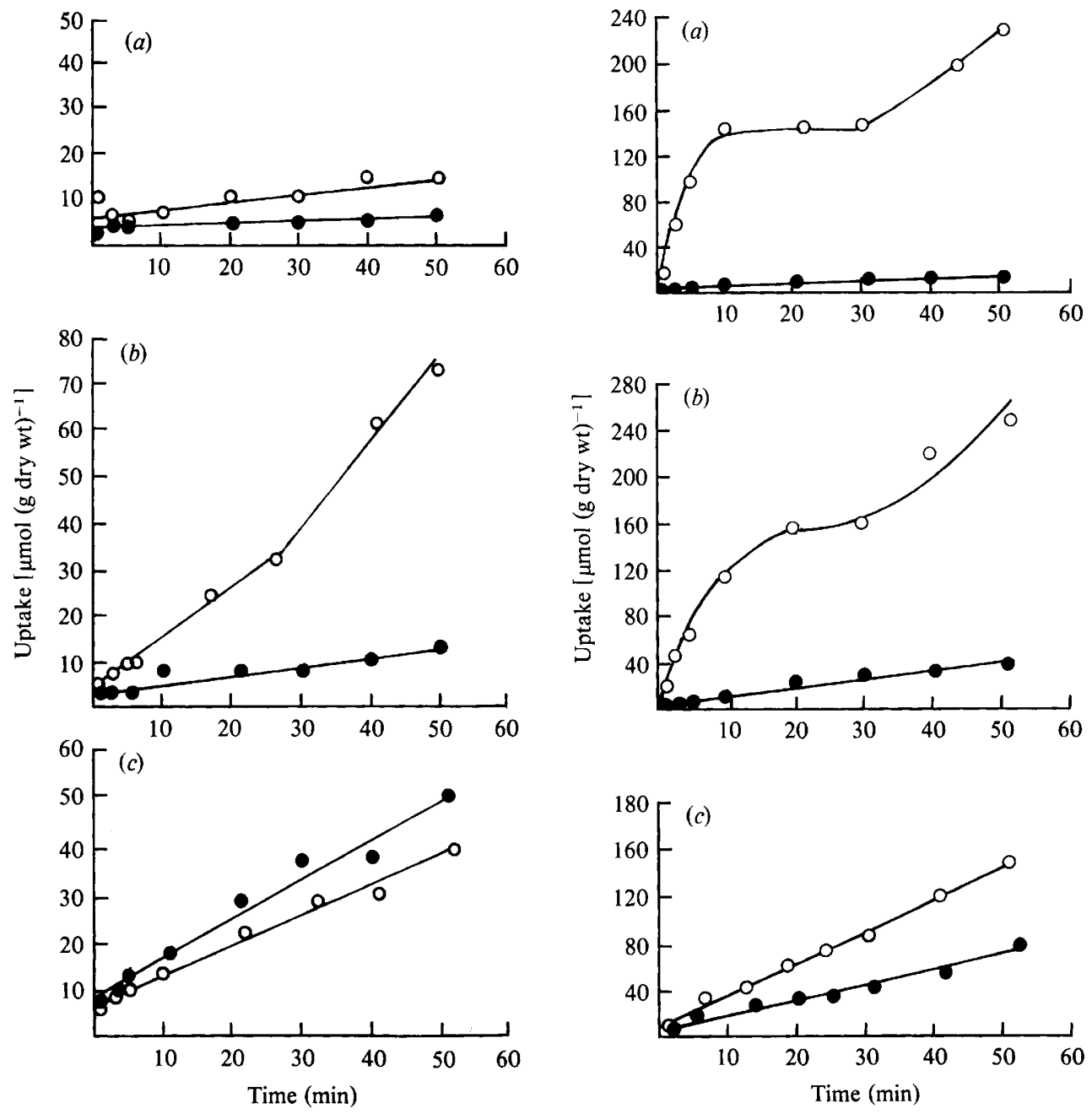

Fig. 3

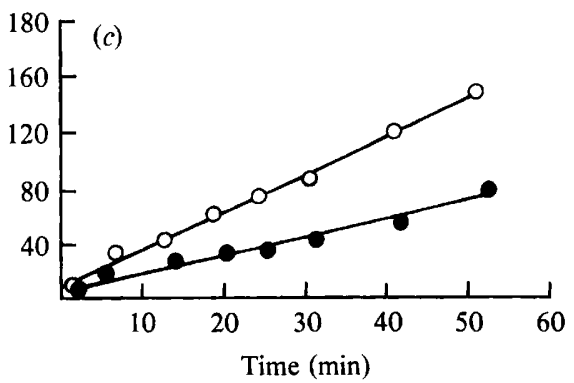

Fig. 4

Fig. 3. Uptake of [U-14 C]glycerol ( $10 \mathrm{mM})$ in the absence of $(O)$ and presence $(O)$ of glucose $(10 \mathrm{~mm})$ in (a) glucose-grown, (b) glucose plus glycerol-grown and (c) glycerol-grown J802 cells. Similar results were obtained in duplicate experiments.

Fig. 4. Uptake of $\mathrm{D}-\left[1 \mathrm{1}^{14} \mathrm{C}\right] \mathrm{galactose}(10 \mathrm{mM})$ in the absence $(\mathrm{O})$ and presence $(\mathrm{O})$ of glucose $(10 \mathrm{~mm})$ in $(a)$ glucose-grown, $(b)$ glucose plus galactose-grown and $(c)$ galactose-grown J802 cells. Similar results were obtained in duplicate experiments.

(g dry wt $)^{-1}$ in duplicate control experiments] was only partially inhibited by dinitrophenol. The uptake rate in the presence of $1 \mathrm{mM}$-dinitrophenol [0.9 and $1.2 \mu \mathrm{mol}$ glycerol $\left.\mathrm{min}^{-1}(\mathrm{~g} \text { dry wt })^{-1}\right]$ was of the same order as the initial uptake rate $\left[1.2\right.$ and $1.2 \mu \mathrm{mol}$ glycerol $\left.\mathrm{min}^{-1}(\mathrm{~g} \mathrm{dry} \mathrm{wt})^{-1}\right]$,

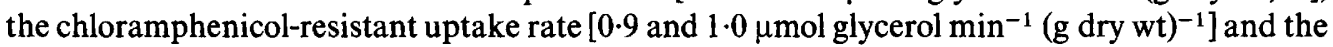
rifampicin-resistant uptake rate $\left[1 \cdot 1\right.$ and $1.0 \mu \mathrm{mol}$ glycerol $\left.\mathrm{min}^{-1}(\mathrm{~g} \text { dry wt })^{-1}\right]$ with glucose plus glycerol-grown cells.

\section{Glucose repression and galactose uptake}

The immediate uptake of galactose by cells grown in glucose and glucose plus galactose (Fig. 4) implies the presence of a galactose uptake system that does not require galactose for induc- 
tion. When $10 \mathrm{~mm}$-glucose was present during the uptake transport was drastically inhibited. Glucose also inhibited transport of galactose in galactose-grown cells by more than $50 \%$.

Rifampicin $\left(100 \mu \mathrm{g} \mathrm{ml}^{-1}\right)$ and chloramphenicol $\left(50 \mu \mathrm{g} \mathrm{ml}^{-1}\right)$ very effectively inhibited the secondary phase of galactose uptake in glucose-grown cells $\left[1.2 \mu \mathrm{mol}\right.$ galactose $\min ^{-1}$ (g dry $\mathrm{wt})^{-1}$ in control experiments], but did not affect galactose uptake in control, chloramphenicol and rifampicin experiments in galactose-grown cells $\left[7 \cdot 7,3.6\right.$ and $7.8 \mu \mathrm{mol}$ galactose $\min ^{-1}(\mathrm{~g}$ dry wt $)^{-1}$, respectively] or the initial rapid uptake rates in control, chloramphenicol and rifampicin experiments in glucose and glucose plus galactose-grown cells $[9 \cdot 1,9 \cdot 8$ and $12.0 \mu \mathrm{mol}$ galactose $\min ^{-1}$ (g dry wt) ${ }^{-1}$, respectively]. Dinitrophenol $(1 \mathrm{mM})$ reduced galactose uptake by galactose-grown cells from 4.1 and $3.7 \mu \mathrm{mol}$ galactose $\min ^{-1}$ (g dry wt) ${ }^{-1}$ to 0 in duplicate control experiments, and sodium iodoacetate $(1 \mathrm{mM})$ plus sodium azide $(30 \mathrm{~mm})$ reduced control galactose uptake rates of 8.1 and $12.7 \mu \mathrm{mol} \mathrm{min}^{-1}\left(\mathrm{~g} \mathrm{dry} \mathrm{wt}^{-1}\right.$ to 0 in glucose-grown cells.

The effects of a range of glucose concentration $(5-200 \mathrm{mM})$ on the rate of uptake of $10 \mathrm{mM}$ galactose in galactose-grown cells were investigated. A simple parabolic inhibition curve was seen, with a 25 -fold inhibition of uptake in the presence of $200 \mathrm{~mm}$-glucose. This eliminated the possibility that a second, glucose-resistant galactose uptake system was in operation.

To investigate further the nature of this inhibition, galactose-grown cells were supplied with different concentrations of galactose in the presence and absence of $20 \mathrm{~mm}$-glucose. Reciprocal (Lineweaver-Burk) plots were prepared for both sets of data. Following regression analysis, the points of intersection of the axes and hence the $K_{\mathrm{s}}^{-1}$ and $V_{\max }$ values, were calculated using the least squares procedure. In the presence of glucose, $K_{\mathrm{s}}$ increased from $6 \cdot 1$ (range $\pm 1 \cdot 1$ ) to $17 \cdot 2$ $\pm 0 \mathrm{~mm}$ (mean of two determinations), i.e. affinity decreased, whilst $V_{\max }$ decreased from $5.4 \pm$ 0.2 to $3.0 \pm 0.4 \mu \mathrm{mol} \mathrm{min}{ }^{-1}$ ( $\mathrm{g}$ dry $\left.\mathrm{wt}\right)^{-1}$ (mean of two determinations). This suggested the involvement of both competitive and non-competitive inhibition.

\section{Glucose repression and fructose uptake}

The uptake of $\mathrm{D}-\left[\mathrm{U}^{-14} \mathrm{C}\right]$ fructose $(20 \mathrm{~mm})$ by cells grown on glucose alone $(10 \mathrm{~mm})$, glucose plus fructose $(50 \mathrm{~mm}$ each) and fructose alone $(50 \mathrm{mM})$, in the presence and absence of glucose $(20 \mathrm{~mm})$ closely resembled the uptake seen for galactose. The rate of fructose uptake $[\mu \mathrm{mol}-$ $\left.\min ^{-1}(\mathrm{~g} \text { dry wt})^{-1}\right]$ in the absence or presence of glucose, respectively, were as follows: in glucose-grown cells, first 8.7 then 0 then 4.2 (glucose absent) or 0.4 (glucose present); in glucose plus fructose-grown cells, first $7 \cdot 0$ then 0 then 2.3 or $0 \cdot 4$; and in fructose-grown cells, $2 \cdot 1$ or 0.8 . Similar results were obtained in duplicate experiments. As with galactose uptake, rifampicin and chloramphenicol inhibited the induction of the secondary phase of fructose uptake in glucose-grown cells, but did not inhibit a fully-induced (fructose-grown) system.

The rates of uptake of fructose $\left[\mu \mathrm{mol} \mathrm{min}^{-1}\left(\mathrm{~g} \mathrm{dry} \mathrm{wt}^{-1}\right]\right.$ were as follows: glucose-grown cells in the absence or presence of $100 \mu \mathrm{g} \mathrm{ml}^{-1}$ rifampicin, first 5.8 then 0 then $5 \cdot 6$, or first $5 \cdot 7$ then 0.8 , respectively; glucose-grown cells in the absence or presence of $50 \mu \mathrm{g} \mathrm{ml}^{-1}$ chloramphenicol, first 4.0 then 1.5 then 4.0 , or first 9.9 then 1.0 , respectively; and fructose-grown cells with no antibiotics, $50 \mu \mathrm{g} \mathrm{ml}^{-1}$ chloramphenicol or $100 \mu \mathrm{g} \mathrm{ml}^{-1}$ rifampicin present, $6.0,5.9$ or 6.0 , respectively. Similar results were obtained in duplicate experiments.

Dinitrophenol $(1 \mathrm{mM})$ reduced fructose uptake in fructose-grown cells from 5.6 and $7.7 \mu \mathrm{mol}$ fructose $\min ^{-1}$ (g dry wt) ${ }^{-1}$ to 0 (in duplicate experiments). The effect on fructose uptake of changing the fructose concentration in fructose-grown cells, in the presence and absence of glucose, was investigated as for the galactose system. When glucose was added the $K_{\mathrm{s}}$ increased only slightly from $46.9 \pm 1$ to $47.8 \pm 0.4 \mathrm{~mm}$ (mean of two determinations), whilst the $V_{\max }$ values, although they varied between two different determinations, showed a reduction from $46.5 \pm 15.7$ to $17.8 \pm 4.0 \mu \mathrm{mol} \mathrm{min}^{-1}(\mathrm{~g} \text { dry wt})^{-1}$. This implied, at least for this concentration of inhibitor, that the effect of glucose on fructose uptake was a non-competitive inhibition.

\section{The isolation of 2-deoxyglucose-resistant mutants}

In order to exploit the analytical power of a genetic approach, attempts were made to find mutants in the glucose repression system(s). The approach was to supply the cell with a carbon source whose utilization was known to be glucose-repressible, together with a glucose analogue 


\section{Table 3. Doubling times of the parental and Dog ${ }^{\mathrm{R}}$ mutants on various carbon sources}

Values were taken from the growth curves of cultures grown in $50 \mathrm{ml} \mathrm{BM}$ in $500 \mathrm{ml}$ flasks as detailed in Methods. Each value is the mean of duplicate determinations unless stated otherwise.

\begin{tabular}{|c|c|c|c|c|c|c|c|}
\hline Strain & Glucose & Cellobiose & Maltose & Arabinose & Fructose & Galactose & Glycerol \\
\hline J802 (wild-type) & $1 \cdot 4$ & $1 \cdot 5$ & $3 \cdot 1$ & $4 \cdot 2$ & $5 \cdot 2$ & $2 \cdot 9$ & $4 \cdot 2$ \\
\hline $\mathrm{J} 845\left(\mathrm{G}^{-}\right)$ & $43 \cdot 4$ & $10 \cdot 9^{*}$ & $16 \cdot 9$ & $3 \cdot 0$ & $4 \cdot 6$ & 1.4 & $2 \cdot 7$ \\
\hline $\mathrm{J} 846\left(\mathrm{G}^{+}\right)$ & $3 \cdot 3$ & 1.9 & $2 \cdot 8 \dagger$ & $2 \cdot 4$ & $2 \cdot 0$ & 1.8 & 3.0 then 6.8 \\
\hline $\mathrm{J} 847\left(\mathrm{G}^{ \pm}\right)$ & $9 \cdot 7$ & 9.8 & $7 \cdot 5$ & $2 \cdot 8$ & $4 \cdot 0$ & $2 \cdot 4$ & $3 \cdot 3+$ \\
\hline
\end{tabular}

that could not be metabolized but was nonetheless capable of activating the glucose repression system and hence of preventing utilization of the alternative carbon source. This provided a strong selective pressure for mutants that had lost their glucose repression system and/or the ability to transport the inhibitor.

The glucose analogues, $\alpha$-methylglucoside and 2-deoxyglucose (DOG), were tested over a range of concentrations for their ability to inhibit growth of strain J802 (NF agaA7) in the presence of arabinose, glycerol, galactose or fructose on NMMB. It was found that $\alpha$-methylglucoside could be used as a sole carbon source, so no further use was made of it. However, sensitivity to $100 \mathrm{~mm}$-DOG was observed on all four carbon sources. DOG-resistant $\left(\operatorname{Dog}^{\mathrm{R}}\right)$ colonies were seen on the arabinose and glycerol plates. Resistant colonies were obtained at a frequency of $6 \times 10^{-5}$ on arabinose plates in the absence of mutagenesis. They all grew well on both arabinose and glycerol in the presence of DOG $(50 \mathrm{~mm})$. Thus, DOG resistance was not specific to any one carbon source utilization system but affected at least two. All the mutants grew on arabinose, glycerol, fructose, galactose, mannitol, mannose, gluconate, rhamnose and pyruvate, and resembled the parental strain (J802) in their inhibition of strains lacking SCP1 and their inability to utilize agar. However, the majority could not grow on glucose, cellobiose or starch, and grew on maltose very poorly (and are therefore termed glucose-negative, or $\mathrm{G}^{-}$). The other mutants could be somewhat arbitrarily divided (by visual inspection of replicants on test plates) into those that grew well on all carbon sources (glucose-positive, or $\mathrm{G}^{+}$) and those that grew less well on glucose and maltose (glucose-poor, or $\mathrm{G}^{ \pm}$). Representatives of these three phenotypic classes (somewhat broad in the case of $\mathrm{G}^{ \pm}$), J845 $\operatorname{dog}-1\left(\mathrm{G}^{-}\right), \mathrm{J} 846 \operatorname{dog}-2\left(\mathrm{G}^{+}\right)$and $\mathrm{J} 847 \operatorname{dog}-3\left(\mathrm{G}^{ \pm}\right)$were used for further studies. Growth rates of these strains on different carbon sources were measured in liquid medium (Table 3). The responses to glucose, cellobiose and maltose confirmed those seen on solid media.

Since $\operatorname{Dog}^{\mathrm{R}}$ mutants selected on arabinose were resistant to DOG on glycerol, resistant colonies were also selected from J802 on $100 \mathrm{mM}$-DOG plus $20 \mathrm{~mm}$-glycerol to test for the reciprocal effect. Again, the different carbon source utilization phenotypes could be discerned, which correspond to the $\operatorname{Dog}^{\mathrm{R}}$ classes on arabinose. The apparent spontaneous frequency of mutation to $\operatorname{Dog}^{\mathrm{R}}$ in the presence of glycerol was $1.5 \times 10^{-5}$. All the $\operatorname{Dog}^{\mathrm{R}}$ mutants selected on glycerol were $\operatorname{Dog}^{\mathrm{R}}$ on arabinose.

\section{Glucose uptake in wild-type and Dog ${ }^{\mathrm{R}}$ mutants}

The phenotypes of $\mathrm{J} 845\left(\mathrm{G}^{-}\right)$and/or $\mathrm{J} 847\left(\mathrm{G}^{ \pm}\right)$might be explained if they had defects in DOG or glucose transport. Glucose uptake was therefore investigated in arabinose-grown $\mathrm{J} 802$, J845, J846 and J847 cultures. The results obtained (Fig. 5) clearly demonstrate that the glucose uptake system does not require glucose for its induction in arabinose-grown cells and that none of these mutants is significantly impaired in glucose uptake. There was reproducible evidence of a second phase of uptake in strain J847 but none in strain $\mathrm{J} 845$. This probably reflects the partial nature of the inability to use glucose in strain J847. However, the levelling off of uptake in both of these mutants, even when ten times the substrate concentration was used, is consistent with there being a defect further along the glucose metabolic pathway. 


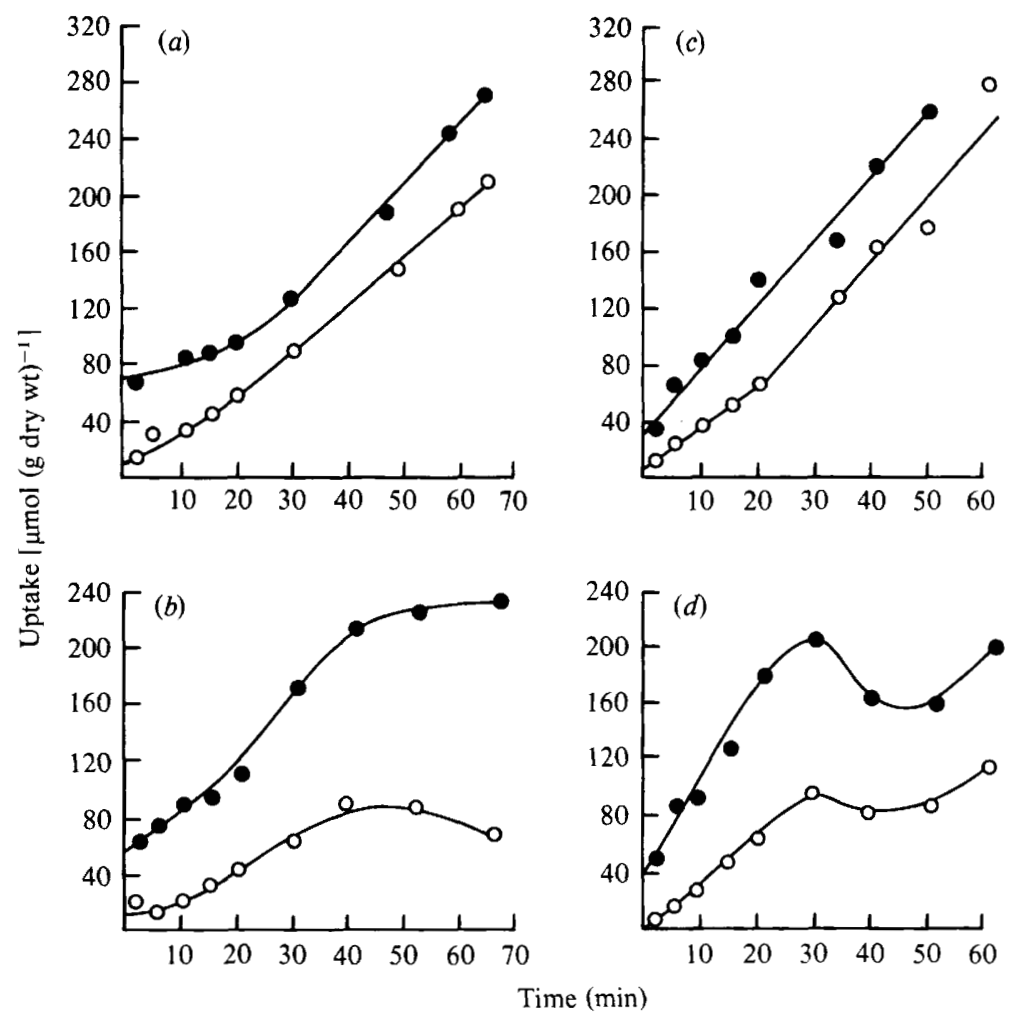

Fig. 5. Uptake of D-[U-14 C]glucose in arabinose-grown cells of $(a) \mathrm{J} 802,(b) \mathrm{J} 845\left(\mathrm{G}^{-}\right)$, (c) $\mathrm{J} 846\left(\mathrm{G}^{+}\right)$ and $(d) \mathrm{J} 847\left(\mathrm{G}^{ \pm}\right)$. Similar results were obtained in duplicate experiments. Glucose was present in the uptake medium at a concentration of $10 \mathrm{~mm}(\mathrm{O})$ or $100 \mathrm{mM}(\odot)$.

\section{Are the 2-deoxyglucose-resistant mutants derepressed?}

The DOG selection was based on the prediction that the resultant mutants would lack glucose repression, at least for utilization of the carbon sources on which they were selected. Since no carbon source-specific $\operatorname{Dog}^{R}$ mutants were found, the mutants were apparently affected in a general repression system. To test this hypothesis, each of the strains was grown in glucose plus arabinose, glucose plus galactose, and glucose plus glycerol, and the uptake of arabinose, galactose or glycerol was examined in the presence and absence of rifampicin. If the cells were derepressed already, uptake should have been seen in the presence or absence of rifampicin. [In the case of J845 $\left(\mathrm{G}^{-}\right)$the cultures grew poorly; see below.] Indeed it was found that all the strains were fully induced for arabinose, galactose, and glycerol uptake (data not shown), indicating a pleiotropic loss of glucose repression in the mutants.

Effect of glucose on fructose and galactose utilization in J845 (glucose non-utilizing) on solid medium

Since the defect in $\mathrm{J} 845\left(\mathrm{G}^{-}\right)$was not in a transport function, it was expected that the strain would be glucose-sensitive on fructose or galactose-containing NMMB, because glucose, which would not itself be metabolized, should cause inhibition of the respective transport systems with the result that the cells would have no carbon source. In confirmation of this there was no greater growth of J845 on glucose plus either galactose or fructose than on glucose alone, although the strain grew well on galactose and fructose in the absence of glucose, and on arabinose regardless of the presence or absence of glucose.

Can 2-deoxyglucose inhibit fructose and galactose transport?

As DOG appears to be able to act as an analogue for glucose in the glucose repression system, 


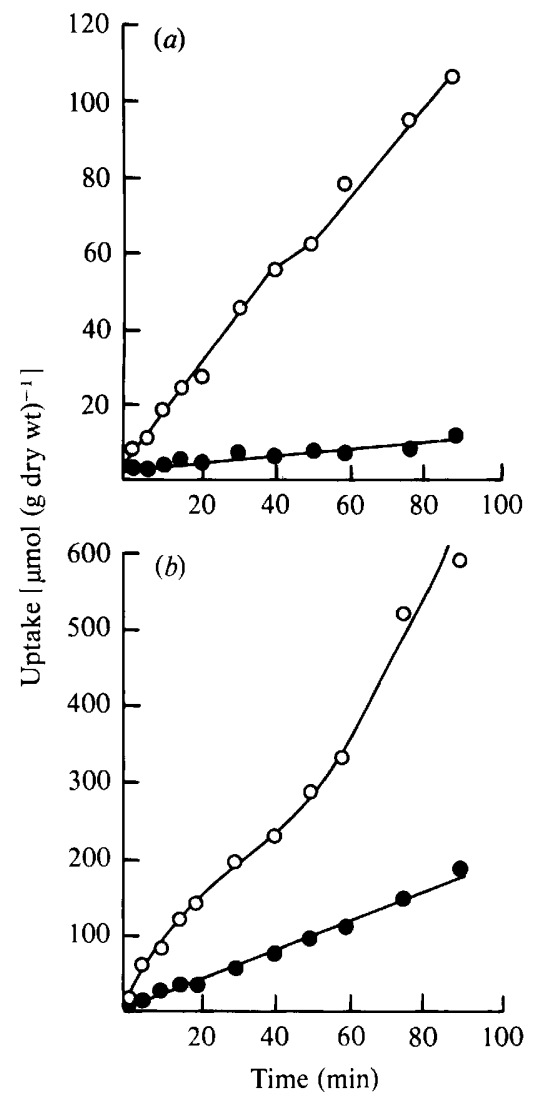

Fig. 6. Effect of 2-deoxyglucose (DOG) on (a) D-[U-14C]fructose (20 mM) uptake in glucose-grown and (b) $\mathrm{D}-\left[1-{ }^{14} \mathrm{C}\right]$ galactose $(10 \mathrm{mM})$ uptake in glucose plus galactose-grown $\mathrm{J} 802$ cells. Similar results were obtained in duplicate experiments in the absence $(O)$ and presence $(O)$ of $50 \mathrm{~mm}$-DOG.

its ability to act as a glucose analogue in the glucose inhibition of the transport of galactose and fructose was also tested. The results obtained (Fig. 6) clearly demonstrate that it can.

\section{Genetic analysis of Dog ${ }^{\mathrm{R}}$ mutants}

In preliminary mapping studies with $\mathrm{J} 845$, $\mathrm{J} 847$ and $\mathrm{J} 855$, every aspect of the mutant phenotype $\left(\mathrm{G}^{-}\right.$or $\mathrm{G}^{ \pm}$, DOG resistance and colony morphology) showed complete co-segregation, strongly suggesting that a single mutation in each case was responsible for the whole phenotype. These mapping studies were not extensive enough to allow unambiguous mapping of the lesions (Hodgson, 1980).

An attempt was made to obtain partial revertants of $\operatorname{dog}-1$ (J845) which had regained the ability to use glucose but retained DOG resistance. The spontaneous frequency of reversion to glucose utilization for one experiment was $1 \times 10^{-5}$. Of 62 thrice-purified revertant colonies, 61 proved to be $\mathrm{G}^{+} \operatorname{Dog}^{\mathrm{s}}$, i.e. were phenotypically apparently true revertants. They had also lost the compact grey colony morphology of $\mathrm{J} 845$ grown on $\mathrm{CM}$. One colony gave only poor growth on glucose and had intermediate DOG resistance. It grew as well as J845 on arabinose, glycerol and galactose, but far better than J845 (though more poorly than J802) on cellobiose and glucose; like $\mathbf{J} 845$, it responded poorly to maltose. The response to cellobiose suggested that the revertant differed from $J 847\left(\mathrm{G}^{ \pm}\right.$Cellobiose $\left.{ }^{-} \operatorname{Dog}^{\mathrm{R}}\right)$. Thus no partial revertants of the desired phenotype were discovered in this limited search, suggesting that DOG and glucose interacted with the same target. 


\section{DISCUSSION}

\section{Arabinose uptake}

The results obtained strongly indicate glucose repression of a respiratory energy-dependent arabinose-induced arabinose uptake system. The inhibition of induction by rifampicin and chloramphenicol, the former at the same concentration as was found to inhibit uridine incorporation by wild-type cells and wild-type RNA polymerase activity in vitro (Chater, 1974, and personal communication), indicates that repression was at the transcription level.

The lack of induction of arabinose uptake in glucose-grown wild-type bacteria when arabinose alone was added, even if the cells were monitored for $2 \mathrm{~h}$ after the addition of arabinose, might indicate that glucose plus arabinose-grown cells had been 'primed' by the previous diffusion of arabinose into the bacteria. In the case of glucose-grown bacteria arabinose had to enter the cells and glucose derepression had to occur before induction was possible. The difference may have been critical in the race between induction of enzymes necessary for uptake and utilization of the available energy source, and death of the very densely suspended cells. It was found (data not shown) that glucose non-repressible cells (e.g. J846 and J847) were able to induce arabinose uptake after growth on glucose, which indicates that time to undergo glucose derepression is a major contribution to the cells' inability to respond fast enough. The time required for release of arabinose plus glucose-grown cells from glucose repression and induction of arabinose uptake (about 7-15 $\mathrm{min}$ ) was short when compared to the doubling time of cells grown on glucose $(2 \mathrm{~h})$ and arabinose $(4 \mathrm{~h})$. This might explain why attempts to find a lag during diauxic growth were unsuccessful.

\section{Glycerol uptake}

The results from studies of the glycerol uptake system were more complicated in that two glycerol-induced systems were detected. One of these systems was glucose-repressible (again at the level of transcription, from the rifampicin and chloramphenicol studies), but was sensitive to dinitrophenol, suggesting that it is an active transport system. This active transport system for glycerol appears to be the first reported in a bacterium (Lin, 1976). The system also appears not to be inhibited by glucose.

The second system was not glucose-repressible but appeared to be glucose-inhibited. The similarity of uptake rates in the glycerol plus glucose-grown cells in the presence of rifampicin and chloramphenicol, with the residual uptake rate in cells treated with dinitrophenol, indicates that the second uptake system does not depend on respiratory energy, i.e. it probably operates via a facilitated diffusion mechanism.

\section{Galactose and fructose uptake}

The galactose and fructose uptake systems (both of which depended on respiration energy) appear not to require induction by the respective sugars. The cessation of uptake in cells grown in glucose or glucose plus the sugar under investigation strongly suggests that a steady-state of sugar import and export had been obtained. If this was so, it clearly implies that the enzymes for the further metabolism of the sugar under investigation were not present and therefore still needed to be induced. The initiation of a secondary uptake phase in these cells implies that either these enzymes had now been induced or, conceivably, that a second uptake system alone had been induced. The lack of any observation of any secondary steady-state phases in uptake experiments suggests the former. The induction was inhibited by glucose at the level of transcription. This could have been due to glucose repression and/or the ability of glucose to stop the transport of the inducer into the cell, i.e. inducer exclusion (Magasanik, 1970).

From the studies of $\mathrm{J} 845\left(\mathrm{G}^{-}\right)$on NMMB it appeared that glucose inhibition of galactose uptake was still operating (as was also shown by the poor growth of the cells used to test whether J845 was depressed). However, in the uptake experiments, galactose was taken up at the same rate in the presence or absence of rifampicin, as seen for the fully induced wild-type (data not shown). This implies that enough galactose was entering the cells to induce the system fully, even though glucose could inhibit its transport into the cell. This situation was not seen in wild-type cells (Fig. 4), in which the system remained uninduced even though some galactose must have 
entered the cells (for instance, by non-specific galactose transport, as in J845). This, in turn, implies that the galactose system is under two controls in the wild-type cells, namely, glucose repression and inducer exclusion, and that glucose repression had been lost in J845. The response of $\mathrm{J} 846\left(\mathrm{G}^{+}\right)$and $\mathrm{J} 847\left(\mathrm{G}^{ \pm}\right)$was essentially the same as for $\mathrm{J} 845$, except of course that they could grow in the presence of glucose plus galactose.

The prior existence of galactose and fructose uptake systems in glucose-grown wild-type cells explains their ability to induce the galactose or fructose utilization enzymes (in contrast to the arabinose and glycerol systems) because the inducer could be rapidly imported into the cell and so induction could take place before the cells were incapacitated. The apparent affinities of the galactose and fructose transport systems for their respective substrates in the absence of glucose were low ( $5.0 \mathrm{mM}$ or $7.2 \mathrm{mM}$ for galactose, and $46.8 \mathrm{mM}$ or $46.9 \mathrm{mM}$ for fructose). The high $K_{\mathrm{s}}$ value for fructose was probably reflected by the poor growth rate seen on it (Table 1) and the requirement for $50 \mathrm{~mm}$ fructose before any growth was seen. Sabater \& Asensio (1973) reported apparent transport $K_{\mathrm{m}}$ values of $1 \mathrm{mM}, 1.5 \mathrm{~mm}$ and $3 \mathrm{~mm}$ for glucose, mannose and fructose, respectively, in another strain of $S$. violaceoruber.

The changes in $V_{\max }$ between cell batches in both fructose and galactose uptake experiments indicated that cells prepared independently of each other were in a different physiological state even though they were identically prepared and treated. However, even taking this into account, it would appear that fructose transport was inhibited in a non-competitive manner by glucose, indicating that the fructose transport system was not also used for the transport of glucose. The response of galactose transport to glucose was less easily interpreted as simply competitive or non-competitive. As DOG (an uncleavable substrate) also caused inducer exclusion, a direct inhibition of the uptake mechanism was suggested.

It is perhaps worthwhile to note that there are several similarities and differences between the reports of Sabater \& Asensio (1973) on their strain and the findings here. They reported that glucose-grown cells did not transport arabinose although they did transport fructose. However, in their strain glucose did not inhibit fructose uptake nor did inhibitors of respiration and glycolysis. It should be noted that the cells were also dealt with less speedily and it is perhaps as a consequence of this that they failed to see a second period of fructose uptake in glucose-grown cells even though they had shown previously (Sabater et al., 1972) that a fructose kinase was inducible.

\section{The nature of the glucose repression system of catabolism in S. coelicolor A3(2)}

Studies with the $\operatorname{Dog}^{\mathrm{R}}$ mutants demonstrate a glucose repression system in $S$. coelicolor A3(2) which allowed repression at the level of transcription of the arabinose and one of the glycerol uptake systems, and also the fructose and galactose metabolism systems. The ability of the Dog ${ }^{\mathrm{R}}$ mutants to grow in arabinose, glycerol, fructose and galactose more rapidly than strain $\mathrm{J} 802$ indicates, perhaps, that the degree of derepression in the mutants is greater than can be achieved in the wild-type.

Wild-type Streptomyces coelicolor A3(2) has the ability to degrade agar and use it as a sole carbon source (Hodgson \& Chater, 1981). Zones of extracellular agar breakdown were reduced in the presence of glucose or cellobiose on medium containing ammonium as the nitrogen source (Hodgson, 1980). This enabled a direct selection for glucose derepressed mutants. A mutant (J855, dog-5) was isolated from NTG-treated spores that still produced an agarase zone in the presence of cellobiose. Further testing demonstrated a carbon source utilization profile similar to $\mathrm{J} 847\left(\mathrm{G}^{ \pm}\right)$and resistance to DOG, which strongly implied that extracellular agarase production was under the control of the same glucose repression system.

From the physiological evidence the defects in the $\mathrm{G}^{-}$mutant appear to be in glucose kinase. The defect in $\mathbf{J} 845$ must be after transport but before conversion of fructose 6-phosphate to fructose 1,6-diphosphate (via phosphofructokinase), since J845 was able to use fructose as a carbon source. Likewise, mannitol and mannose are utilized via fructose 6-phosphate, and they were also utilized by $\mathrm{J} 845$. Since the only enzymic processes between glucose uptake and the formation of fructose 6-phosphate are the phosphorylation step mediated by hexokinase and isomerization mediated by phosphohexoisomerase, J845 must be defective in one of these 
processes. The isomerase could not have been lost because the mutant still utilized galactose, which is metabolized via glucose 1-phosphate and glucose 6-phosphate. Thus J845 must be defective in glucose kinase. By the same argument J847 and J855 must also be glucose kinase mutants. This deduction has recently been confirmed for $\mathrm{J} 845$ by studies with cell-free extracts (E. T. Seno, personal communication). $\mathrm{J} 846\left(\mathrm{G}^{+}\right)$might be either a very leaky glucose kinase mutant or defective in another gene product involved in catabolite repression. The latter implies a negatively acting (i.e. repressing) control system. It should be emphasized that these arguments rest on the premises that $S$. coelicolor A3(2) uses glycolysis as the main method of glucose catabolism as reported for other streptomycetes (Cochrane, 1961) and that the pathways of galactose, fructose and mannitol catabolism are the same as reported in other bacteria that use glycolysis. (This is true for fructose metabolism in a closely-related streptomycete; Sabater et al., 1972.)

The use of DOG to isolate mutants that lack glucose phosphorylating enzymes has also been reported in Saccharomyces cerevisiae (Lobo \& Maitra, 1977). However, this required the construction of strains that carried only one of the three known glucose phosphorylating enzymes present in the wild-type strain. Any effects on glucose repression systems were not reported. $\operatorname{Dog}^{\mathrm{R}}$ mutants were also isolated from wild-type Saccharomyces cerevisiae (Heredia \& Sols, 1964). These proved to contain a constitutive phosphatase that could dephosphorylate the toxic end product 2-deoxyglucose 6-phosphate.

The genetic studies (co-segregation of $\mathrm{G}^{-}$or $\mathrm{G}^{ \pm}$and $\operatorname{Dog}^{\mathrm{R}}$ phenotype) and reversion experiments with $\mathrm{J} 845\left(\mathrm{G}^{-}\right)$demonstrated that the glucose kinase activity and the glucose repression systems were intricately related. The failure to obtain $\operatorname{Dog}^{\mathrm{R}} \mathrm{G}^{+}$revertants of $d o g-1$ suggest that glucose 6-phosphate accumulation or glucose kinase activity per se is involved in glucose repression.

Attempts to detect any involvement of cyclic AMP in glucose repression failed (Hodgson, 1980). Evidence of a compound that competitively inhibited binding of $\left[{ }^{3} \mathrm{H}\right]$ cyclic AMP to catabolite repressor protein was found, but neither this substance nor added bona fide cyclic AMP could be inactivated by beef heart phosphodiesterase in the crude cell extract. The concentration of cyclic AMP did not vary with the carbon source on which the cells were grown, nor was there any other evidence that might have implicated a role in control of glucose repression.

The most frequent class of $\operatorname{Dog}^{\mathrm{R}}$ mutants (mutation frequency $6 \times 10^{-5}$ ) has apparently lost an enzymic function; therefore, mutation to DOG resistance should provide a useful system for studying forward mutations in S. coelicolor A3(2). It may also be valuable that reversion of such mutants can be selected directly by their growth on glucose. Also, since the isolation of glucosederepressed mutants of $S$. coelicolor A3(2) is so simple, it would be interesting to isolate similar mutants of streptomycetes that produce antibiotics which have been shown to have glucoserepressible enzymes in their synthetic pathways (examples are listed in Table 1 of Martin \& Demain, 1980). The antibiotics produced by $S$. coelicolor A3(2), methylenomycin A (Wright \& Hopwood, 1976 a ) and actinorhodin (Wright \& Hopwood, 1976b) are not glucose-repressed and are unaffected by loss of glucose repression per se, although loss of glucose catabolism did lead to loss of actinorhodin synthesis unless acetate was supplied exogenously (Hodgson, 1980).

I would like to thank Keith Chater for his helpful discussions and tireless support during this work. Thanks are also due to Eddie Arthur for help with the statistical analysis. Finally, I would like to thank David Hopwood, Gene Seno and Lucy Shapiro for many useful comments on the manuscript. This work has been supported by the donation of a Research Studentship to the John Innes Institute by Pfizer (U.K.) Ltd.

\section{REFERENCES}

CHATER, K. F. (1974). Rifampicin-resistant mutants of Streptomyces coelicolor A3(2). Journal of General Microbiology 80, 277-290.

Cochrane, V. W. (1961). Physiology of Actinomycetes. Annual Review of Microbiology 15, 1-26.

Heredia, C. F. \& Sols, A. (1964). Metabolic studies with 2-deoxyhexoses. II. Resistance to 2-deoxyglu- cose in a yeast mutant. Biochimica et biophysica acta 86, 224-228.

HoDGSON, D. A. (1980). Carbohydrate utilization in Streptomyces coelicolor A3(2). Ph.D. thesis, University of East Anglia, Norwich, U.K.

Hodgson, D. A. \& Chater, K. F. (1981). A chromosomal locus controlling extracellular agarase pro- 
duction by Streptomyces coelicolor and its inactivation by chromosomal integration of plasmid SCP1. Journal of General Microbiology 124, 339-348.

HopwoOD, D. A. (1967). Genetic analysis and genome structure in Streptomyces coelicolor. Bacteriological Reviews 31, 373-403.

Hopwood, D. A., Chater, K. F., Dowding, J. E. \& Vivian, A. (1973). Advances in Streptomyces coelicolor A3(2) genetics. Bacteriological Reviews 37, 371405.

KutZNER, H. J. \& WaKsman, S. A. (1959). Streptomyces coelicolor Muller and Streptomyces violaceoruber Waksman and Curtis, two distinctly different organisms. Journal of Bacteriology 78, 528-538.

LiN, E. C. C. (1976). Glycerol dissimilation and its regulation in bacteria. Annual Review of Microbiology 30, 535-578.

Lobo, Z. \& MaItra, P. K. (1977). Resistance to 2deoxyglucose in yeast : a direct selection of mutants lacking glucose phosphorylating enzymes. Molecular and General Genetics 157, 297-300.

MaGasanik, B. (1970). Glucose effects: inducer exclusion and repression. In The Lactose Operon, pp. 189219. Edited by J. R. Beckwith \& D. Zipser. New York: Cold Spring Harbor Laboratory.

MarTin, J. F. \& Demain, A. L. (1980). Control of antibiotic biosynthesis. Microbiological Reviews 44, 230 251.
Neujahr, H. Y. \& Ewaldsson, B. (1964). Counting of weak $\beta$-emitters in bacterial cells by means of the liquid scintillation method. Analytical Biochemistry 8, 487-494.

Sabater, B. \& Asensio, C. (1973). Transport of hexoses in Streptomyces coelicolor. European Journal of Biochemistry 39, 201-205.

Sabater, B., Sebastian, J. \& Asensio, C. (1972). Identification and properties of an inducible and highly specific fructokinase from Streptomyces violaceoruber. Biochimica et biophysica acta 284, 414-420.

VIVIAN, A. (1971). Genetic control of fertility in Streptomyces coelicolor A3(2): plasmid involvement in the interconversion of UF to IF strains. Journal of General Microbiology 69, 353-364.

WheELIS, M. H. \& WeLLS, B. (1974). Uniform growth of Streptomyces coelicolor in liquid medium. In John Innes Annual Report, 1974, p. 77. Norwich: John Innes Institute.

WRIGHT, L. F. \& HoPwOOD, D. A. (1976a). Identification of the antibiotic determined by SCP1 plasmid of Streptomyces coelicolor A3(2). Journal of General Microbiology 95, 96-106.

Wright, L. F. \& HoPwOOD, D. A. (1976b). Actinorhodin is a chromosomally determined antibiotic in Streptomyces coelicolor A3(2). Journal of General Microbiology 96, 289-297. 